\title{
The Intersection of Evaluation by Mediators and Informed Consent: Warning the Unwary
}

\author{
LELA P. LOVE* AND JOHN W. COOLEY* $†$
}

\section{INTRODUCTION}

Anyone who dares to explore the field of informed consent in alternative dispute resolution quickly comes to appreciate the quagmire of differing expert viewpoints, of conflicting (or silent) codes of conduct, statutes and rules, of divergent definitions of processes, and of the complexity of the topic generally. ${ }^{1}$ For example, there are vigorous inquiries and debates about whether pro se parties, in the context of court-annexed mediation, should be informed about their legal rights before being encouraged to settle their case in mediation, ${ }^{2}$ about what amount of information parties in mediation should receive concerning confidentiality and its exceptions, ${ }^{3}$ and about the process

* Professor of Law, Director of the Kukin Program for Conflict Resolution, Benjamin N. Cardozo School of Law, Yeshiva University. B.A., Harvard University, 1973; M.Ed., Virginia Commonwealth University, 1975; J.D., Georgetown University, 1979.

** Adjunct Professor of Law, Northwestern University School of Law. Member of JAMS panel of mediators and arbitrators, Chicago, Illinois. B.S., United States Military Academy at West Point, New York, 1965; J.D., University of Notre Dame Law School, 1973.

† The authors thank John Lande, Jacqueline Nolan-Haley, Josh Stulberg, Chris Fugarino, Tracey Pastan and the editors and staff of the Ohio State Journal on Dispute Resolution for their comments, guidance, and generous support.

1 See generally Jacqueline M. Nolan-Haley, Informed Consent in Mediation: A Guiding Principle for Truly Educated Decisionmaking, 74 NOTRE DAME L. REV. 775 (1999); Samuel J. Imperati, Alternative Dispute Resolution Symposium Issue: Mediator Practice Models: The Intersection of Ethics and Stylistic Practices in Mediation, 33 WILLAMETTE L. REV. 703 (1997).

2 Nolan-Haley, supra note 1 , at 834-38.

3 The Uniform Mediation Act ("UMA") and a variety of other laws create a privilege for mediation communications and then carve out exceptions to confidentiality protections. Professor James Coben created a videotape for a CLE program offered on October 22, 2001 at the 4th Annual ADR Institute, sponsored by the Minnesota Bar Association in Minneapolis, which illustrated the futility and destructiveness of trying to explain confidentiality and catalogue its numerous exceptions in the context of a mediator's opening statement. (videotape on file with the authors). Nonetheless, mediators must find meaningful ways to present confidentiality, including indicating that exceptions to coverage exist. 
of mediation and the credentials of the mediator. ${ }^{4}$

This essay explores only one facet of the question of informed consent: what mediators should tell parties before providing an evaluation or opinion on the merits of a legal question (or some other aspect of a situation where parties request an opinion and the mediator is credentialed in the relevant area). What might comprehensive ethics codes provide? What does good practice dictate? What warnings for the unwary must be given?

Our purpose is not to extend the debate on whether evaluative mediator behaviors can be incorporated within the meaning of mediation, ${ }^{5}$ or on whether evaluative mediation is an oxymoron ${ }^{6}$ that should be replaced by

${ }^{4}$ In Minnesota, for (an unusual) example, compensated mediators must provide parties with a written summary of their qualifications prior to the mediation. MINN. STAT. $\S 572.37$ (2004) ("No individual may act as a mediator pursuant to the Minnesota Civil Mediation Act for compensation without providing the individuals to the conflict with a written statement of qualifications prior to beginning mediation. The statement shall describe educational background and relevant training and experience in the field."). A violator risks criminal sanctions. Id. ("A person who violates this section is guilty of a petty misdemeanor."). For a thoughtful critique of this law, see James R. Coben \& Peter $\mathrm{N}$. Thompson, The Haghighi Trilogy and the Minnesota Civil Mediation Act: Exposing a Phantom Menace Casting a Pall Over the Development of ADR in Minnesota, 20 HAMLINE J. PUB. L. \& POL'Y 299 (1999) (arguing that criminal sanctions are absurd in this context and a waste of criminal justice resources).

${ }^{5}$ A partial list of articles focusing on the question of mediator evaluation includes: Leonard L. Riskin, Understanding Mediators' Orientations, Strategies, and Techniques: A Grid for the Perplexed, I HARV. NEGot. L. REV. 7 (1996) (including mediators who have an evaluative orientation on a grid describing the mediation universe); Kimberlee $\mathrm{K}$. Kovach \& Lela P. Love, Mapping Mediation: The Risks of Riskin's Grid, 3 HARV. NEGOT. L. REV. 71 (1998) (arguing that a mediator should maintain a facilitative orientation); Marjorie Corman Aaron, ADR Toolbox: The Highwire Art of Evaluation, 14 ALTERNATIVES TO THE HiGH COST OF LITIG. 62 (1996) (describing appropriate uses for mediator evaluation and recommending specific mediator strategies); James J. Alfini, Evaluative versus Facilitative Mediation: A Discussion, 24 FLA. ST. U. L. REV. 919 (1997); Robert B. Moberly, Mediator Gag Rules: Is It Ethical for Mediators to Evaluate or Advise?, 38 S. TEX. L. REV. 669 (1997) (arguing against ethical rules that prohibit mediator evaluation); Jeffrey W. Stempel, Beyond Formalism and False Dichotomies: The Need for Institutionalizing a Flexible Concept of the Mediator's Role, 24 FLA. ST. U. L. REV. 949 (1997) (endorsing flexible mediation that permits judicious use of evaluative techniques); Joseph B. Stulberg, Facilitative Versus Evaluative Mediator Orientations: Piercing the "Grid" Lock, 24 FLA. ST. U. L. REV. 985 (1997) (arguing that the central values of the mediation process appear least congruent with the notion of the evaluative mediator); Lela P. Love \& Kimberlee K. Kovach, ADR: An Eclectic Array of Processes, Rather than One Eclectic Process, 2000 J. DiSP. RESOL. 295 (arguing that when mediators provide evaluations the process should be labeled mediation and neutral evaluation).

${ }^{6}$ Kimberlee K. Kovach \& Lela P. Love, "Evaluative" Mediation Is An Oxymoron, 14 ALTERNATIVES TO HIGH COST OF LITIG. 31 (1996). 
different descriptors, or on whether certain types of evaluation constitute the practice of law. ${ }^{7}$ In fact, a significant portion of the marketplace, particularly in the court-annexed and lawyered arenas, seems drawn to mediators who provide evaluations as part of their repertoires. ${ }^{8}$ In addition, many scholars and practitioners argue that requested mediator evaluations can advance meaningful self-determination and informed consent. ${ }^{9}$ In a recent study of participants' experience in special education mediation, scholar Nancy Welsh found that parents valued evaluative mediator behaviors that helped move toward resolution so long as parents felt the mediator understood their concerns. ${ }^{10}$ Since it is being done in the field, with reported success, it becomes important that it be done in a manner most constructive to party self-determination, which is the first principle of mediation. ${ }^{11}$

${ }^{7}$ Carrie Menkel-Meakow, Ethics in Alternative Dispute Resolution: New Issues, No Answers from the Adversary Conception of Lawyers' Responsibilities, 38 S. TEX. L. REV. 407, 424 (1997) (arguing that when mediators evaluate cases by applying legal principles to specific facts, they are engaging in the practice of law); Maureen E. Laflin, Preserving the Integrity of Mediation Through the Adoption of Ethical Rules for Lawyer-Mediators, 14 NotRe DAME J.L. ETHICS \& PUB. POL'Y 479, 505 (2000).

${ }^{8}$ Laflin, supra note 7, at 486 (noting that studies show a preference among lawyers for evaluative mediators); Robert A. Baruch Bush, Substituting Mediation for Arbitration: The Growing Market for Evaluative Mediation, and What it Means for the ADR Field, 3 PEPP. DiSP. RESOL. L.J. 111, 122 (2002) (explaining the growth of evaluative mediation as an arbitration substitute which filled a vacuum created by arbitration becoming more formal, expensive, and "judicialized").

${ }^{9}$ Nolan-Haley, supra note 1, at 797; James H. Stark, The Ethics of Mediation Evaluation: Some Troublesome Questions And Tentative Proposals, from an Evaluative Lawyer Mediator, 38 S. TEX. L. REV. 769, 795 (1997); James H. Stark, Preliminary Reflections on the Establishment of a Mediation Clinic, 2 CLINICAL L. REV. 457, 487 (1996); Donald Weckstein, In Praise of Party Empowerment-And of Mediator Activism, 33 WILLAMETTE L. REV. 501, 526 (1997) (noting that party and lawyer preference for evaluative mediation is "consistent with disputant empowerment"); Leonard Riskin, Standards of Professional Conduct in Alternative Dispute Resolution, 1995 J. DisP. RESOL. 95, 101-02 (commenting that "evaluation can enhance self-determination"); Robert B. Moberly, supra note 5, at 772 (1997) (arguing that self-determination calls for evaluation if parties express that as their preference).

10 Nancy A. Welsh, Stepping Back Through the Looking Glass: Real Conversations with Real Disputants About Institutionalized Mediation and Its Value, 19 OHIO ST. J. ON DisP. RESOL. 573, 644 (2004).

11 Model Standards OF CONduCt FOR MEDiators Standard 1 (2005) ("A mediator shall conduct a mediation based on the principle of party self-determination."). See also FLA. R. CERTIFIED \& CT. APP'TED MED. 10.230 (2005) ("Mediation is based on concepts of communication, negotiation, facilitation, and problem-solving that emphasize: (a) self determination ...."); VA. SUP. CT. R. Pt. $6 \S 2$, R. PROF'L CONDUCT 2.11(d) (2005) ("A lawyer-mediator may offer evaluation of, for example, strengths and weaknesses of positions, assess the value and cost of alternatives to settlement, or assess 
This article will explore principles to guide mediators in responsibly performing their duty of ensuring that parties give their informed consent prior to a mediator jumping into a requested evaluative or decisional role. In articulating principles and guidelines, we will have to answer: What should be said to parties? When should it be said? How can consent be given? Additionally, once consent is given, the evaluation must comport with an appropriate standard of care. How careful must a mediator be in providing an opinion or professional advice? Should a mediator providing legal analysis, for example, be held to the same standard of care as a lawyer providing legal advice to a client? Of course, any mediator must comply with rules and regulations that may limit evaluative conduct in particular jurisdictions and on particular panels. We begin by discussing informed consent.

\section{INFORMED CONSENT}

\section{A. Background}

In many contexts, our legal system measures "consent" to a process, an agreement, the assumption of a risk, or a waiver of rights against a standard of disclosure and adequate understanding. ${ }^{12}$ Model Rule of Professional Conduct 1.0(e) for lawyers, for example, defines informed consent with respect to attorneys and clients as follows: "[T]he agreement by a person to a proposed course of conduct after the lawyer has communicated adequate information and explanation about the material risks of and reasonably available alternatives to the proposed course of conduct." 13 The quality of the necessary information-or disclosure-as well as the consent itself, may depend upon the sophistication and representation of a client. In some cases, "consent" must be evidenced in writing. ${ }^{14}$

In considering the necessary party consent to an arbitrator serving as a settlement facilitator (the opposite situation of a mediator serving as an

the barriers to settlement (collectively referred to as evaluation) only if such evaluation is incidental to the facilitative role and does not interfere with the lawyer-mediator's impartiality or the self-determination of the parties.").

12 Nolan-Haley, supra note 1 , at 778.

13 MOdEL RULES OF PROF'L CONDUCT R. 1.0(e) (2004).

14 See, e.g., MOdel Rules Of PROF'L CONDUCT R. 1.7(b) (2004) ("Notwithstanding the existence of a concurrent conflict of interest..., a lawyer may represent a client if ... (4) each client gives informed consent, confirmed in writing."); id. R. 1.9(a) ("A lawyer who has formerly represented a client in a matter shall not thereafter represent another person in the same or a substantially related matter in which that person's interests are materially adverse to the interests of the former client unless the former client gives informed consent, confirmed in writing."). 
evaluator), the International Bar Association's ("IBA") Working Group, which formulated the IBA Guidelines on Conflicts of Interest in International Arbitration, ${ }^{15}$ concluded:

Considering the sensitive position of the arbitrator as potential settlement facilitator... the taskforce and the Working Group determined that the parties must give their express agreement prior to the commencement of such a process. This express agreement will be considered an effective waiver of any potential conflict of interest that might arise from the arbitrator's participation in settlement or from any information that the arbitrator may learn in the process. After some debate and consideration of the issue, the Working Group agreed that the express agreement need not be in writing, but could be, for instance, an oral agreement reflected in the minutes of a hearing. ${ }^{16}$

In other words, med-arb (which is similar to a mediator taking on a decisional role) requires a high level of informed consent.

The standard of care with respect to informed consent as it applies to lawyers and arbitrators is relatively well defined, as contrasted with that applying to mediators. A review of the literature on informed consent in mediation reveals disagreement and confusion regarding what, precisely, parties should be informed of prior to consenting to participate in mediation. Despite the widespread use of the term "informed consent" in the literature and the disparities in its definition, the Model Standards of Conduct for Mediators, adopted by a joint committee of the American Bar Association, the Society of Professionals in Dispute Resolution and the American Arbitration Association in 1994, and its 2005 revisions, ${ }^{17}$ do not refer to the term "informed consent," perhaps because no one fully understands or agrees to what it means in the mediation context. ${ }^{18}$ The silence is surprising because "informed consent" provides the foundation for self-determination and

15 IBA Guidelines on Conflicts of Interest in Int'l Arbitration (2004), available at http://www.ibanet.org/images/downloads/guidelines\%20text.pdf.

16 For the Working Group, Otto L O de Witt Wijnen et al., Background Information on the IBA Guidelines on Conflicts of Interest in International Arbitration, 5 BUS. L. INT'L 433, 452 (2004).

${ }^{17}$ MODEL STANDARDS OF CONDUCT FOR MEDIATORS (2005), available at http://www.mediate.com/pdf/ModelStandardsofConductforMediatorsfinal05.pdf; MODEL STANDARDS OF CONDUCT FOR MEDIATORS (1994), available at http://moritzlaw.osu.edu/dr/msoc/pdf/original_standards.pdf.

18 The Model Standards do refer to parties making "informed choices as to process." MODEL STANDARDS OF CONDUCT FOR MEDIATORS Standard I.A. (2005). We feel that this general prescription does not have the force or clarity of a more explicit duty to obtain informed consent as urged in this article. 
voluntariness in the selection of, and party participation in, a particular ADR process. ${ }^{19}$ According to Professor Jacqueline Nolan-Haley, in her classic article on informed consent,

A robust theory of informed consent requires that parties be educated about mediation before they consent to participate in it .... Informed consent serves the values of autonomy, human dignity, and efficiency. It guards against coercion, ignorance, and incapacity that can impede the consensual underpinnings of the mediation process. 20

Deconstructing these lofty aspirations into concrete mediator practices becomes the challenge.

\section{B. Informed Consent in Mediation}

While the term "informed consent" is not always used, many existing regulations of and policy statements about mediation require disclosure and (sometimes) party consent. These have the impact of mandating informed consent even where that term is not used. Examples of various components of "informed consent" relevant to adequate party education about the mediator providing legal or other professional evaluations are covered by existing guidelines that address the following: parties' understanding and choice of different mediation models (e.g., facilitative, evaluative, transformative, or some combination of these) $;{ }^{21}$ consequences of revealing

${ }^{19}$ See generally Nolan-Haley, supra note 1.

$20 \mathrm{Id}$. at 812.

21 See Imperati, supra note 1, at 744; VA. SuP. CT. R. Pt. 6 § 2, R. Prof'L ConduCT 2.11(d) and (e)(1)(i) (2005) (providing "(d) A lawyer-mediator may offer evaluation of ... strengths and weaknesses of positions, assess the value and cost of alternatives to settlement or assess the barriers to settlement... .only if such evaluation is incidental to the facilitative role and does not interfere with the lawyer-mediator's impartiality or the self-determination of the parties," and "(e) Prior to the mediation session a lawyermediator shall: (1) consult with prospective parties about (i) the nature of the mediation process...."); Or. Jud. Court-Connected Mediator Qualifications §1.4(3) (2005) (providing that a mediator must "[i]nform the participants prior to or at the commencement of the mediation of . . . (a) The nature of mediation, the role and style of the mediator, and the process that will be used..."). See also OR. UNIF. TRIAL CT. R. 12.530(2)(b) (2003); CAL. CT. R. 1620.7(c)(1) and (g) (2005) (providing "(c) . . at or before the outset of the mediation the mediator must provide all participants with a general explanation of: (1) The nature of the mediation process," and " $(\mathrm{g})$ The mediator must inform the parties of the general natures of the different [dispute resolution processes]."); GA. Alternative DisP. Resol. Rules, App. C, ch. 1(A)(I)(A) (2005) ("A principal duty of the mediator is to fully explain the mediation process. This explanation 
information during any one process that might be used for decision making in another process; 22 parties' right to know when the transition from one process to another is occurring; ${ }^{23}$ parties' opportunity to select another neutral for the subsequent process; ${ }^{24}$ the mediator's subject matter expertise; ${ }^{25}$ the mediator offering legal information; 26 restrictions on the neutral's performance of professional services in any capacity (other than the neutral capacity);27 and limitations on the use of mediator evaluation. ${ }^{28}$

should include... the role of the mediator as a neutral person who will facilitate the discussion between the parties but who will not coerce or control the outcome ... [and] the procedure which will be followed during the mediation session."); ALM SUP. JUD. CT. R. 1:18, §9(c) (2004) ("The neutral shall make every reasonable effort to ensure that each party to the dispute resolution process ... understands the nature and character of the process."); Ass'N FOR CONFLICT RESOL., THE AUTHORIZED PRACTICE OF MEDIATION 6 (Proposed Draft 2004) [hereinafter APM Report], available at http://www.acrnet.org/pdfs/upl-draftrpt-aug04.pdf.

${ }^{22}$ CAL. CT. R. 1620.7(g) (2005) ("A mediator must exercise caution in combining mediation with other alternative dispute resolution (ADR) processes and may do so only with the informed consent of the parties .... The mediator must inform the parties of the general natures of the different processes and the consequences of revealing information during any one process that might be used for decision making in another process ....").

${ }^{23}$ CAL. CT. R. 1620.7(g) (2005) ("If the parties consent to a combination of processes, the mediator must clearly inform the participants when the transition from one process to another is occurring."); ALM SUP. JUD. CT. R. 1:18, \& 9(c)(i) ("A neutral shall make every reasonable effort to ensure at every stage of the proceedings that each party understands the dispute resolution process in which he or she is participating.").

${ }^{24}$ CAL. CT. R. 1620.7(g) (2005) ("The mediator must inform the parties of ... different processes ... and must give the parties the opportunity to select another neutral for the subsequent process.").

${ }^{25}$ VA. SuP. CT. R. Pt. 6 § 2, R. PROF'L ConduCt 2.11(e)(1)(iii) (2005) (providing "(e) Prior to the mediation session a lawyer-mediator shall: (1) consult with prospective parties about... (iii) the lawyer-mediator's approach, style and subject matter expertise....").

${ }^{26}$ VA. SUP. CT. R. Pt. $6 \S 2$, R. PROF'L ConduCt 2.11(c) (2005) (“A lawyer-mediator may offer legal information if all parties are present or separately to the parties if they consent. The lawyer-mediator shall inform unrepresented parties or those parties who are not accompanied by legal counsel about the importance of reviewing the lawyermediator's legal information with legal counsel."); GA. ALTERNATIVE DISP. RES. R. APP. C, ch. $1(\mathrm{~A})(1)(\mathrm{A})(4)(2005)$ (requiring that a mediator provide "[a]n explanation of the fact that the mediator will not give legal or financial advice and that if expert advice is needed, parties will be expected to refer to outside experts").

27 CAL. CT. R. 1620.7(d) (2005) ("A mediator must inform all participants, at or before the outset of the first mediation session, that during the mediation he or she will not represent any participant as a lawyer or perform professional services in any capacity other than as an impartial mediator."); FLA. R. CERTIFIED \& CT. APP'TED MED. 10.340(d) (2005) ("During a mediation, a mediator shall not provide any services that are not 
In reviewing literature on informed consent in mediation, several perspectives are helpful in framing a theory of obtaining informed consent for evaluative mediator conduct: institutional definitions, the distinction between participation and outcome consent, the aspiration of "high quality consent," and the notion of critical (or decision) points. We review each below.

\section{Institutional Definitions of Informed Consent in Mediation}

Three examples of policy statements and rules on informed consent display a range of concerns and approaches.

The August 28, 2004 Draft of the Association for Conflict Resolution's ("ACR") Proposed Policy Statement on "The Authorized Practice of Mediation," issued for comment by the Board of Directors of ACR, defines informed consent as follows:

Informed Consent. Respect for the nature of the parties' voluntary participation in a mediation calls for that participation to be grounded in informed consent. In other words, parties have the right to "understand the nature of the process, the procedures, the particular role of the neutral, and the parties' relationship to the neutral." This is a continuing right. ${ }^{29}$

The Uniform Rules on Dispute Resolution of the Supreme Judicial Court of Massachusetts provide an even more basic approach:

Informed Consent. The neutral shall make every reasonable effort to ensure that each party to the dispute resolution process (a) understands the nature and character of the process, and (b) in consensual processes, understands and voluntarily consents to any agreement reached in the process. ${ }^{30}$

The Virginia Supreme Court Rules add considerable meat to the bones of

directly related to the mediation process.").

28 VA. SuP. CT. R. Pt. $6 \S 2$, R. Prof'L ConduCt 2.11(e)(1)(ii) (2005) (providing "(e) Prior to the mediation session a lawyer-mediator shall: (1) consult with prospective parties about ... (ii) the limitations on the use of evaluation, as set forth in subparagraph (d) . ...”). See VA. SuP. CT. R. Pt. 6 § 2, R. PROF'L CONDUCT 2.11(d) (2005), supra note 11, subpara. (d).

${ }^{29}$ APM Report, supra note 21, at 6. A final version of the Proposed Policy Statement has not yet been approved, according to an email from David Hart, CEO of ACR on October 7, 2005, to Jack Cooley (footnotes and citations omitted) (on file with authors).

30 ALM SUP. JUD. CT. R. 1:18, § 9(c) (2003). 
the ACR draft Policy Statement and the Massachusetts Rule:

Informed Consent to Mediator's Approach. The rule focuses on the informed consent of the prospective mediation clients to the particular approach, style and subject matter expertise of the lawyer-mediator. This begins with consultation about the nature of the mediation process, the limitations on evaluation, the lawyer-mediator's approach, style, and subject-matter expertise and the parties' expectations regarding the mediation process. If the parties request an evaluative approach, the lawyermediator shall explain the risk that evaluation might interfere with mediator impartiality and self-determination. ${ }^{31}$

At the simplest level, each of these prescriptive definitions of informed consent obligate the mediator to ensure that parties understand the nature of the process. ACR's Proposed Policy Statement adds that parties must understand the procedures to be utilized and the role of the mediator as critical elements of informed consent, emphasizing the ongoing character of the neutral's duty to keep the parties informed about the process. The Virginia rule spells out in far more detail the meaning of informed consent. In each case, however, the requirement that the mediator obtain the parties' informed consent supports a notion of mediation as a voluntary process, where informed consent makes participation and self-determination meaningful.

\section{Participant and Outcome Consent in Mediation}

Professor Jacquelyn Nolan-Haley identifies two types of consent that operate during a mediation- "participation consent" and "outcome consent":

Meaningful consent must be voluntary and should be given with an understanding of its attendant consequences. Consent to participate in the mediation process, what I will call "participation consent," has several dimensions. It involves a conscious, knowledgeable decision to enter into the mediation process and to continue participating in mediation through good faith negotiations. This is more than a matter of signing a form agreement to mediate. It involves an ongoing commitment to honor the integrity of the mediation process....

Consent to the outcome reached in mediation, what I will call "outcome consent," involves a separate decision to accept the agreement that is reached with an understanding of its content, its consequences, and what options are being waived by such consent. This requires sufficient factual

31 VA. SUP. CT. R. Pt. 6 § 2; R. PROF’L CONDUCT 2.11 n.3 (2005). 
and substantive information. In this sense then, disclosure and consent are linked concepts and, without sufficient disclosures, "outcome consent" is suspect. $^{32}$

In important ways participation consent is not meaningful without full understanding about the process. Such understanding includes whether or not the mediator will be facilitating party evaluation or supplying neutral evaluation (or both). To the extent that "outcome consent" rests on a mediator evaluation, the basis for the evaluation should be known. If, for example, the mediator misrepresents her expertise or fails to highlight ways in which her evaluation is based on different information than what a judge would have, the "outcome consent" might be flawed.

\section{3. "High-quality" Consent in Mediation}

Professor John Lande has argued in favor of achieving what he calls "high-quality consent" in mediation. ${ }^{33}$ Lande urges that parties should exercise responsibility for making decisions in a dispute by considering the situation sufficiently and without excessive pressure. He offers seven factors intended to provide principals, their attorneys, mediators, or other observers with practical criteria for determining the quality level of consent of a principal in mediation. Those factors are as follows:

(1) explicit identification of the principals' goals and interests, (2) explicit identification of plausible options for satisfying these interests, (3) the principals' explicit selection of options for evaluation, (4) careful consideration of these options, (5) the mediators' restraint in pressuring principals to accept particular substantive options, (6) limitation on use of time pressure, and (7) confirmation of principals' consent to selected options. $^{34}$

Professor Lande suggests that the development of a fairly clear and generally accepted conception of "high-quality consent," as represented by these seven factors, may be an important factor in the improvement of both lawyering practices and mediation practices in future years. The notion of "high-quality consent" supports a conception of mediation premised on party control of process and outcomes. Such control without meaningful understanding is illusory.

32 Nolan-Haley, supra note 1, at 819-20 (footnotes and citations omitted).

33 John Lande, How Will Lawyering and Mediation Practices Transform Each Other?, 24 FLA. ST. U. L. REV. 839 (1997).

${ }^{34}$ Id. at 869. 


\section{4. "Decision Points" Relating to Consent in Mediation}

Finally, Samuel Imperati highlights "decision points" where a mediator might usefully direct parties to consider important elements of the process. Below are several such "decision points" relating to evaluative mediator conduct:

- How much subject matter expertise should the mediator have, and when and how should such expertise be used?

- Should the mediator offer options or propose settlement terms? If yes, under what circumstances?

- Should the mediator offer opinions? If yes, under what circumstances?

- Should the mediator raise issues, claims or defenses? If yes, under what circumstances?

- Should the mediator offer "legal information" as contrasted with "legal advice?"35

Imperati's "decision points" or questions provide a useful checklist for evaluative mediators to ensure party consent and agreement prior to using evaluative tools. This, in turn, serves party control and self-determination.

\section{Informed Consent for Mediator Evaluation}

With respect to understanding and agreeing to a classic evaluation on the part of a mediator, ${ }^{36}$ informed consent is a relatively straightforward concept. Simply put, parties are entitled to understand what they are requesting (or what is being proposed by the mediator) and to be forewarned of dangers they might face prior to their consenting to the mediator's provision of an

35 Imperati, supra note 1 , at 743.

36 By "classic evaluation" we want to posit a bright line situation. For example, a classic evaluation would be where a mediator agrees to provide an opinion on the likely court outcome (a dollar amount or a monetary range) in a personal injury action. At the same time, we acknowledge that there is a large grey area between facilitative mediator reality testing and the provision of an evaluation. Margaret Shaw, a well known and highly respected mediator, trainer, and scholar, has advocated that evaluation should be viewed on a continuum of behaviors rather than posited as an "either/or." See Margaret L. Shaw, Style Schmyle! What's Evaluation Got To Do With It?, DISP. RESOL. MAG., Spring 2005 , at 19 . Certainly a continuum exists, but so does a bright line. While it is hard to find the line, there is one between reality-testing and opinion-giving, between mediation and arbitration-or, to extend the point, between pornography and art, and illusion and reality. This is circular in that while arguing that a line exists, one must also acknowledge lack of unanimity on where the line is! 
evaluation. Once adequately warned, parties are deemed to have assumed the risk voluntarily if they consent and hence be responsible for the consequences of their choice.

What then constitutes consent to engage in an evaluative process? Any definition of informed consent should be carefully crafted to describe the precise scope of the consent to an evaluative process. At a minimum, a party's consent should cover elements that current mediation court rules generally require when an evaluation is contemplated, requested, or proffered. The scope of a party's consent should encompass a freely-made, voluntary decision: (1) to participate in a specific type of evaluative process based on a clear understanding of the benefits, limitations, and risks associated with the process; (2) to be satisfied with the specifically described role of the neutral and the neutral's related ethical responsibilities in the evaluative process; and (3) to be satisfied with the nature and amount of any additional fees and costs charged by the neutral in conducting the evaluative process.

\section{DECISIONAL MEDIATOR CONDUCT TRIGgERING THE NEED FOR INFORMED CONSENT}

\section{A. Evaluative or Decisional Mediator Behaviors}

As noted above, in September 2004 the Board of Directors of the Association for Conflict Resolution issued for comment a Proposed Policy Statement entitled "The Authorized Practice of Mediation." 37 The purpose of the policy statement was "to delineate proper and improper mediation practices." ${ }^{38}$ In considering what conduct constituted the authorized practice of mediation, the Task Force that studied the topic examined the following evaluative mediator moves ${ }^{39}$ (with examples provided by the authors of this article in parentheses):

- Advise parties about their legal rights or responsibilities. (e.g., "You do not have standing to bring this claim.")

- Apply legal precedent to the specific facts of the dispute. (e.g., "Your supervisor may be a poor manager, but the situation you describe is not race discrimination.")

37 See APM Report, supra note 21.

38 Id. at 2.

39 The Task Force found that the first three moves listed are "improper mediation practice" and the final two moves listed are "mediation practice warranting increased scrutiny depending on context." Id. at 10-11. 
- Offer any personal or professional opinion as to how the court (judge or jury) in which a case has been filed will resolve the dispute. (e.g., "You are not likely to win on appeal.")

- Provide any personal or professional evaluation of the strengths and weaknesses of the case, either directly or implicitly. (e.g., "Your claim for punitive damages is problematic.")

- Recommend a specific course of action. (e.g., "Take this offer. You will not get a better one.")

A mediator's intention to engage in one or more of these behaviors in a mediation session may trigger a duty of the mediator to inform parties that an evaluation is being offered and parties' consent is needed prior to going forward. 40

The line between evaluative or decisional conduct that we describe here, and the "reality testing" of a facilitative mediator is difficult to discern. For example, a mediator facilitating party evaluation may properly facilitate the parties' conversation about applicable law, their discussion about the strengths and weaknesses of their respective cases, and their discussion of alternatives and options. ${ }^{41}$ In pursuit of those goals, the mediator may ask:

- "Have you considered the point Lawyer A made concerning his belief that you do not have standing to bring this claim?"

- "Could you explain to me why you think this is discrimination as opposed to just poor management?"

- "Imagine that you lost your appeal, can you explain why that might have happened?"

- "Have you considered getting legal advice about the claim for punitive damages?"

- "Have you considered the signal you will send by rejecting this offer? If these negotiations break down, tell me again about your litigation option."

Such questions have an evaluative component but-most importantly-are calling on the party to make evaluations. It is the mediator providing her opinion that raises the duty to warn we describe here. ${ }^{42}$

$40 \mathrm{Id}$. at 12 (stating that a "mediator must review with the parties the implications of ... a process change").

41 The Task Force found this conduct to be the authorized practice of mediation. Id. at 9 .

42 Tone, body-language, and gestures can turn an otherwise reality-testing question into an evaluation or opinion. The point is to stay within the advertised frame absent "informed consent" to go elsewhere. 


\section{B. The Danger Inherent in Mediator Evaluations}

What hazards do parties face in electing to have the mediator give an opinion on the merits? Why all the fuss about so-called decisional moves? Why should informed consent be required for mediator opinions?

The following is a list of potential dangers: ${ }^{43}$

- an evaluation might jeopardize the actual or perceived neutrality of the mediator, ${ }^{44}$ which in turn jeopardizes a mediator's continued usefulness; ${ }^{45}$

- an evaluation might interfere with party self-determination (insofar as parties bow to a neutral's expertise and opinion); ${ }^{46}$

- an evaluation made on the basis of incomplete or limited information or in the absence of expert opinions can be highly speculative;

- the evaluator may be wrong (as to facts, the credibility and weight of evidence, the burden of proof, or the law);

- even if the evaluator is right, a subsequent arbitrator, judge or jury may not reach the same conclusion;

- an evaluation based in some part on information obtained in caucuses (without the opportunity for rebuttal by the other side) rests on inferior evidence than the evidence that an arbitrator, judge or jury would have;

- an evaluation might violate the reasonable expectations of the parties regarding the nature of mediation;

- an evaluation may end negotiations by polarizing the parties and entrenching their positions, in effect prolonging rather than shortening litigation (or disputing) where the party disfavored by the evaluation is not willing to compromise and the favored party is entrenched given the neutral's endorsement;

43 See generally Lela P. Love, The Top Ten Reasons Why Mediators Should Not Evaluate, 24 FLA. ST. U. L. REV. 937 (1997) (exploring in more depth the dangers listed here).

44 Laflin, supra note 7, at 497 (stating that a perceived loss of neutrality undermines the disfavored party's perception of a fair process and can result in an unwillingness to continue); Marjorie Corman Aaron, Symposium, Standards of Professional Care in Alternative Dispute Resolution, 1995 J. DiSP. RESOL. 95, 107 (noting that the "loser" in an evaluation may view the mediator as an adversary resulting in the potential loss of perceived neutrality).

45 This observation leads some commentators to recommend evaluations only at the end of a mediation when facilitation has not achieved agreement. See Aaron, supra note 5 , at 62 .

${ }^{46}$ But see supra note 9 and accompanying text. 
- evaluation detracts from the focus on party responsibility for critical evaluation, re-evaluation, and creative problem-solving;

- evaluation by a mediator who has another profession (e.g., law or psychology) can generate cross-profession confusion; ${ }^{47}$

- an anticipated evaluation will importantly effect mediation representation and party negotiation. ${ }^{48}$

Some of these hazards are best illustrated by an example. As you read the example, note that the break-down or harm caused by the evaluation is compounded by no disclosure and no consent.

A landlord-tenant matter. The mediator (who either is or is not a lawyer) in a community dispute resolution center tells the landlord and tenant parties, who are disputing about a pet in the tenant's apartment, that since there is a lease provision precluding pets, that issue should be taken off the table because, legally, the pet must go. (Trouble is: the law is more complicated, providing that where a landlord does not object to a pet within a certain time frame, a no-pet lease provision is waived.)

One can easily imagine a thoughtful evaluation saving parties expense and aggravation of further disputing. However, the evaluation should be requested, proffered in the light of various hazards, and rendered with due care. These ideals were not met in the example above. Here, the mediator's neutrality may well be lost in the eyes of the tenant, who (for whatever set of reasons) feels entitled to have the pet; the evaluation is wrong (or dangerously incomplete); the evaluation may end any hope of successful negotiation and integrative solution, entrenching the landlord in his position of "no pets." If the mediator is a lawyer, then the lawyer should have done adequate research before making the evaluative statement. If the mediator is

${ }^{47}$ Laflin, supra note 7, at 479.

48 See Harold I. Abramson, Mining Mediation Rules for Representation Opportunities and Obstacles, 15 AM. REV. INT'L ARB. 103, 105-06 (2004) [hereinafter Mining Mediation] (stating that giving the mediator power to recommend settlements can "singularly pigeonhole and shape your entire mediation representation strategy ... [inducing the attorney to] approach the mediation more like a judicial process than a negotiation. Instead of viewing the mediator as a facilitator, you may view the mediator as a decision maker. Instead of formulating a negotiation strategy based on meeting parties' interests, you may be impelled to formulate a strategy designed to persuade the mediator to recommend favorable settlement proposals."); Harold I. Abramson, Problem-Solving Advocacy in Mediations: A Model of Client Representation, 10 HARv. Negot. L. REV. 103, 123-28 (2005) [hereinafter Problem-Solving Advocacy] (arguing that the anticipation of mediator evaluation will likely result in attorneys withholding information and hiding flexibility, hence diluting mediation's potential as a problem-solving process). 
not a lawyer, then she could be deemed to have engaged in the unauthorized practice of law. These same dynamics could play out in the context of virtually all case types.

\section{A Duty to Warn}

Given the potential dangers of mediator evaluation and the prescription of informed consent, what doctrines might create a duty to warn and, conversely, liability for a failure to warn?

\section{Torts}

In tort law, to establish negligence, a plaintiff must first prove a duty on the part of the defendant. ${ }^{49}$ For example, the familiar warnings about cigarette smoking on cigarette cartons that alert the consumer of dangers prior to use are a manifestation of the duty to warn. So too are the leaflets accompanying prescription drugs that, read closely, would give any person pause regarding the cure being worse than the disease.

It is not simple, however, to know what or how much to say. If I offer you my horse to ride, must I remind you that riding is dangerous? That the terrain has holes and the horse may trip? That there are branches in the woods and you must duck? Does it make a difference if the horse is a highstrung thoroughbred or a placid school horse? Must I tell you that riding horses can lead to serious injury and death in order to discharge a responsibility I may have that you be informed before you consent to ride?

Once you do consent, how careful must I be? Does it matter if you are a novice or experienced rider? Can I trust your assessment (or my own judgment) on that question? Do I have to be sure your horse's girth (the piece of equipment that holds on the saddle) is tightened? Must I ensure that you are wearing a helmet and have heels on your boots (to prevent the stirrup from slipping)? Laws in some states require that a posted warning indicate that riding can lead to death in order for tort liability to be avoided.

These questions are not unlike those faced by a mediator. Disputes represent crises in human interaction. Approaches to resolving conflicts may have important repercussions on the rest of a disputant's life. Before engaging in a particular process or before changing the chosen process or

49 The elements of a malpractice action include the following: that defendant owed plaintiff a duty; that defendant failed to perform or breached that duty; that the breach was the proximate cause of plaintiff's injuries; and that plaintiff was damaged. See generally Horak v. Biris, 130 Ill. App. 3d 140, 144 (1985) (finding facts sufficient to establish a cause of action for social worker malpractice). 
approach, it seems obvious that disputants must be informed about a proposed approach (or change in approach) and what the repercussions might be.

Generally, customary practice in the relevant arena provides one measure of the requisite standard of care. As Professor Jennifer Shultz writes:

Once legal standards of care for... mediators are determined, violations of these standards will result in negligence. This is important because currently, "accountability really does not exist, because there are no generally accepted standards that must be adhered to, and, consequently it [is] difficult to establish malpractice, no matter how unfair the process or the result." 50

Such a standard needs to be developed, as Professor Shultz points out.

In the torts arena, beyond simple negligence liability arising from a breach of a duty to warn and consequent damages, a mediator who fails to inform and to warn could conceivably be subject to liability for other tortbased conduct. ${ }^{51}$ If the mediator's conduct were egregious enough, a mediator could potentially be held liable for intentional infliction of emotional distress. 52 In addition, an injured party in the appropriate circumstances could charge that the mediator's violation of his duty to inform and warn amounted to an intentional and wrongful interference with his contractual rights or his economic opportunity. ${ }^{53}$

Tort law represents but one theory informing the standard of care applied to mediators in performing the function of obtaining informed consent prior to conducting an evaluation. Other approaches include: contracts and fiduciary duties. These theories are discussed in turn.

\section{Contracts}

For a mediator to be liable under a contract theory for a failure to warn or to obtain informed consent, a party would need to demonstrate a breach of either an implied or express term in the mediation contract. ${ }^{54}$

If a mediator fails to obtain informed consent or to warn about limitations and dangers of a proposed evaluation process to be used, the

50 Jennifer L. Schulz, Mediator Liability: Using Custom to Determine Standards of Care, 65 SASK. L. REV. 163, 178 (2002) (quoting Carol S. Bruch, When to Use and When to Avoid Mediation, 31 FAM. \& CONCILIATION CTS. REV. 101, 107 (1993)).

51 Michael Moffitt, Suing Mediators, 83 B.U. L. REV. 147, 159 (2003).

52 Id. at $159-61$.

$53 \mathrm{Id}$. at 159.

54 Id. at 163 . 
mediator is vulnerable to a party's claim that the mediator violated terms in the contract that were so important to self-determination that they should be implied. As Professor Moffitt observes, " $t]$ he principal term implied into a mediation contract would be a covenant of good faith, binding a mediator to mediate with reasonable skill and care." 55 Where the mediator violates an accepted norm of "reasonable" practice within mediation generally, she may be liable under a contract theory for resulting damages.

The Model Standards of Conduct for Mediators supply a relevant norm that specifically references the mediator's responsibility to obtain the parties' consent for any change in role. Section VI.5. posits a line between the role of mediators and other professionals, and Section VI.8. cautions that any change of role should have the parties' endorsement.

\section{STANDARD VI. QUALITY OF THE PROCESS}

VI.5. The role of a mediator differs substantially from other professional roles. Mixing the role of a mediator and the role of another profession is problematic and thus, a mediator should distinguish between the roles. A mediator may provide information that the mediator is qualified by training or experience to provide, only if the mediator can do so consistent with these Standards....

VI.8. A mediator shall not undertake an additional dispute resolution role in the same matter without the consent of the parties. Before providing such service, a mediator shall inform the parties of the implications of the change in process and obtain their consent to the change. A mediator who undertakes such role assumes different duties and responsibilities that may be governed by other standards. ${ }^{56}$

Beyond liability based on implied contract terms, to the extent that the mediator expressly promises in a contract or opening statement to refrain from providing an evaluation absent agreement of the parties, a breach of such an express term could be actionable.

\section{Provision from a Retainer Agreement}

The mediator's role is to facilitate the resolution of the dispute. Legal evaluations or opinions by the mediator will be given only by consent of all parties and are not to be relied on in resolving this matter. The parties agree that the mediator is not acting as an attorney or legal representative or judge or providing legal advice on behalf of or for the benefit of any party.

-from a Retainer Agreement of Carrie Menkel-Meadow

55 Id. at 166 (footnotes and citations omitted).

56 MODEL STANDARDS OF CONDUCT FOR MEDIATORS, supra note 17. 


\section{Fiduciary Duty}

Some experts contend that mediators owe fiduciary duties to the parties whose dispute they mediate. ${ }^{57}$ Stated more explicitly, "the mediator is said to represent the integrity of the mediation process and it is in this sense ... that the mediator has a special fiduciary relationship with both parties to a dispute." 58 A fiduciary relationship generally is imbued with qualities of trust, confidence, and good faith. ${ }^{59}$ As Professor Chaykin points out:

A mediator actively seeks to gain the trust of the mediatrants in order to maximize effectiveness. Parties to a mediation will reveal the most intimate personal and financial information to the mediator. The parties rely on the mediator to be truthful and honest and to conduct the mediation in such a manner that both parties are treated fairly....

Trust is such an essential element of the mediator's work, it could be argued, that mediators generally should be held to the virtually per se rule applied to trustees and attorneys. Like attorneys, mediators agree to act for the benefit of others; like trustees, they provide advice, guidance, and expertise on affairs of grave importance to the parties. ${ }^{60}$

Mediators may violate the duty of trustworthiness by deceiving parties as to their credentials or by misinforming parties as to the kind of service that will be provided. ${ }^{61}$ Consequently, the failure to obtain the parties' consent for the mediator's provision of an evaluation may give rise to a cause of action for breach of fiduciary duty. Where a court finds the existence of a fiduciary relationship between a mediator and a party, the fiduciary will be under a special duty of full disclosure. ${ }^{62}$ As Professor Chaykin observes, "[e]ven the slightest breach of fiduciary duty may subject the fiduciary to liability." 63

57 Arthur A. Chaykin, Mediator Liability: A New Role for Fiduciary Duties?, 53 U. CIN. L. REV. 731, 732 (1984); see also Nolan-Haley, supra note 1, at 825-26. But see Moffitt, supra note 51, at 167-69.

58 Nolan-Haley, supra note 1 , at 826.

59 Chaykin, supra note 57 , at 740 .

60 Id. at $744-45$.

61 Id. at 750.

62 See generally Horak v. Biris, 130 Ill. App. 3d 140, 145 (1985) (finding that a social worker/therapist violated his fiduciary relationship with his patient and is therefore subject to liability and damages).

63 Chaykin, supra note 57 , at 742 . 


\section{Different Strokes for Different Folks?}

\section{Unrepresented Parties}

Imagine, on the one hand, an unsophisticated, unrepresented, perhaps illiterate party in mediation, and on the other hand, a highly sophisticated, well-heeled, repeat player, represented by a prestigious law firm. The type of disclosures and explanations appropriate from the mediator may well vary. Mediators may owe a heightened duty of disclosure to unrepresented parties than they owe to parties who come to mediation with lawyers. ${ }^{64}$ This heightened duty suggests that extra caution should be exercised in obtaining informed consent prior to a mediator evaluation in such circumstances. Professor Nolan-Haley observes:

Fairness demands that each party understand what it is doing when it engages in mediation decisionmaking. As a general proposition, more information is required for those who may lack the ability to negotiate effectively for themselves. Overall, we must pay more attention to the methodology of process disclosures that are typically given by the mediator. ${ }^{65}$

One can easily imagine an unrepresented party giving undue weight to a mediator's opinion (by mistaking someone sitting in the neutral's chair for a judge), as contrasted with a sophisticated attorney who understands that any one opinion (no matter how credible the source) does not end the controversy. Consequently, mediators should take increased care to ensure that unrepresented parties fully understand the risks and limitations of the proposed evaluative process.

Where parties are represented by counsel, it is still important for mediators to carefully explain the evaluative process in their opening statement and along the way if the process changes. Relying on parties to study mediator retainer agreements (when clients may rely on their lawyers for that service) would be a mistake. The assumption that attorneys understand the difference between mediation and an evaluative process may be a mistake too.

\section{Lay Mediators}

All mediators should describe their relevant credentials to provide an

64 Nolan-Haley, supra note 1 , at 833.

$65 \mathrm{Id}$. at 833 (footnotes and citations omitted). 
evaluation and should have the requisite competence. Lay mediators, ${ }^{66}$ however, must be careful not to give legal or other professional advice. As a general principle, the provision of legal advice by someone who is not licensed to practice law is an actionable offense, and is prohibited in every jurisdiction as the unauthorized practice of law. For example, if we assume that the mediator in the landlord-tenant case described above (who advises a tenant about the effect of a lease provision) was not a licensed attorney, then he would have been prohibited from making that type of evaluation.

By the same token, mediators who are not social workers, psychologists, or psychiatrists should not give advice about the psychological impact of various courses of action.

On the other hand, a license to practice law, psychology or any other profession does not mean one is competent to provide an opinion on a given question. An attorney concentrating in intellectual property may not be competent to evaluate an employment matter-at least not without appropriate research. ${ }^{67}$

\section{PRINCIPLES FOR DISCLOSURE}

So we arrive back at the questions: What principles guide mediators in providing parties with information relevant to the parties' consent to a mediator's changing role? When must a mediator obtain consent to step near (or over) the line into a decisional, evaluative role-into what has been called "evaluative mediation?"68

${ }^{66}$ This term is used here to mean mediators without other professional degrees or credentials.

${ }^{67}$ See Bush, supra note 8, at 124-25 (urging that practitioners of evaluative mediation "be held to standards appropriate for their role as expert case evaluators" and suggesting that only lawyers should provide evaluative mediation in court-ordered or law-related contexts).

68 Professor Leonard Riskin, whose pathbreaking work highlighted the differences between evaluative and facilitative conduct of mediators (see Riskin, supra note 5) has more recently shifted the descriptive terms to "elicitive" and "directive." See Leonard L. Riskin, Decisionmaking in Mediation: The New Old Grid and New New Grid System, 79 NOTRE DAME L. REV. 1 (2003). These new terms may be more helpful in analyzing which conduct might interfere with self-determination. For example, a sharply focused line of questions raising doubts about a party's position or a concerned look after a claim is made may be more directive than an evaluation given after appropriate disclosures and wamings described here. See Margaret L. Shaw, supra note 36, at 19 (pointing out that facilitative mediators can be evaluative and that classification of mediators with these labels risks being confusing and counterproductive). 


\section{A. No Surprises}

No one likes bad surprises. When expectations are lowered by thoughtful warnings, one tends to appreciate what is provided and take precautions against what might cause problems. Furthermore, disclosure and consent passes the burden of responsibility to the person who assumes the risk. If I choose to travel abroad after being forewarned that there are innumerable hassles caused by security checks, I will pack in a manner to assure that my carry-on baggage has my critical and valuable items and that I have reading material to pass away time spent in lines. The lack of surprise when I encounter long lines and lost baggage means that I can enjoy the benefits I receive from foreign travel in a more constructive state of mind.

Adequate warning will enhance a mediator's credibility in that candor and disclosure garners trust. In addition, accurate expectations will allow attorneys to prepare appropriate representation plans and allow clients to make appropriate disclosures. If, however, the task is to persuade the other side and engage in problem solving, the representation and disclosures will be different than they would be if the task is to persuade the neutral in a winlose contest. ${ }^{69}$ Certainly, where a lawyer-mediator has a reputation as both a lawyer and a mediator, he must clarify what frame-or professional identity - he is operating in, and the lawyer representative needs clarity concerning whether she is in a more traditional adversarial arena or in a problem-solving mode.

\section{B. A Clear Warning}

Any warning must indicate, with precision, the service being proffered (e.g., "I will provide you with my best judgment, based solely on the information provided in this mediation, of the likely jury award on this claim.") and the various dangers to the mediation that are entailed.

What would an adequate warning sound like? A mediator warning parties of the hazards outlined above might offer the following:

You have asked me to give an opinion on the likely court outcome of this matter, and I am willing to do that if you both agree to my providing that service. However, you should understand that at least one of you may not like my opinion and may feel I am no longer impartial. And, it may be that I will be inclined toward the evaluation I provide. If that happens, I may be unable to assist you further or may be less effective as a mediator. Also, particularly if you think my opinion is wrong, you may be

${ }^{69}$ See Mining Mediation, supra note 48, at 105; Problem-Solving Advocacy, supra note 48 , at $123-28$. 
disadvantaged by it in subsequent negotiations.

While I will do my best to give you a thoughtful opinion, you should understand I might be wrong-different lawyers come to different conclusions - and my analysis will be based on information that is different from what a judge, arbitrator, or jury would hear. My opinion will be based on more limited evidence than the evidence available in adjudication, since you have not completed discovery. Also, since I have learned information in caucus and from confidential submissions that you have not heard or seen and hence cannot rebut, you must rely on me to separate that out from information I hear in joint session.

In any case, it is very speculative to predict what a particular judge might do. I advise you to listen to your own counsel (or to get legal counsel) to inform you and protect your legal rights.

Also, to the degree we focus on legal rights and the likely court outcome, it may distract you from looking for more creative solutions that might serve your interests better.

Are you sure you want me to give an evaluation?

This sort of statement might be most appropriate when a mediator begins in a facilitative mode, and an evaluation is subsequently requested by the parties. ${ }^{70}$ Of course, the parties could select another neutral to provide the evaluation, but in some cases (for efficiency reasons or because the parties have developed trust and rapport with the mediator), they will want to retain the same neutral. In contexts where the mediator knows in advance that her regular practice encompasses evaluation, a disclosure should be provided earlier and in writing.

\section{Early Warning}

Since the advocacy approach of attorneys and the willingness to share certain types of information of parties may (and should!) depend on their expectations regarding the role of the neutral, that role should be clarified at the earliest point possible-ideally before the mediation begins. There are a variety of ways to accomplish that in addition to the verbal disclosures above.

70 Professor Dwight Golann points out that mediators shift styles with some frequency during the course of a mediation. See Dwight Golann, Variations in Mediation: How-and Why-Legal Mediators Change Styles in the Course of a Case, $2000 \mathrm{~J}$. DISP. RESOL. 41,61 . 
Program administrators can describe with precision the services offered by their panelists, including whether panel mediators offer legal and other professional (psychology, accounting, environmental) advice. For example, the NASD Dispute Resolution Program Mediator Disclosure Report is sent to prospective mediation parties. It describes whether the mediator is evaluative, facilitative or combined. $^{71}$ If the same form indicated whether or not the mediator would give an opinion on the merits of a claim or defense, assuming a request by all parties, it would provide the basis of the informed consent suggested here-so long as the mediator is chosen by (not assigned to) the parties. Or, in an agreement to mediate parties can specify a desired approach regarding opinion and analysis on the merits of an issue in dispute (see excerpted agreement in box giving an example of that approach). Or, the rules and regulations around mediators in particular programs and jurisdictions might provide a clear framework for informing consumers. ${ }^{72}$

Often it is at "final" impasse

\section{Excerpt from a Sample Agreement to Mediate}

Approaches of the Mediator-

The parties agree to select a mediator with the following mix of approaches selected in the section. If the parties cannot or are not ready to agree to all of the mediator approaches at this time, the parties agree that within five business days after selecting the mediator, the mediator shall convene a premediation conference in which the mediator will facilitate a discussion of the mix of mediator approaches and any other issues the parties want to resolve before the mediation session....

Select one for each subject area: [Only provisions relevant to mediator evaluation are included here.]

Manages Process By: Facilitating Predominately Evaluating Predominately Following Transformative Approach Resolve When Dispute Arises

Engage in Evaluation of Legal Issues or Settlement Proposals: None Only After Parties Specifically Consent to What is to be Evaluated Leave to Discretion of Mediator Resolve When Dispute Arises

Harold Abramson, MEDIATION REPRESENTATION: Advocating In a Problem-Solving Process APPENDIX G (2004).

${ }^{71}$ For a description and analysis of the NASD Dispute Resolution Program Mediator Disclosure Report see Shaw, supra note 36, at 18-19.

72 See Nancy A. Welsh, The Thinning Vision of Self-Determination in CourtConnected Mediation: The Inevitable Price of Institutionalization?, 6 HARV. NEGOT. L. REV. 1, 34-52 (2001) (describing the development of Florida's ethical guidelines). 
that mediators offer an evaluation as a last-resort impasse-breaking device. Two points need to be made about "final" impasse. First, it's not over until it's over! Determining what constitutes final impasse is a tricky-and perhaps illusory-affair. Parties can always re-commence negotiations and mediation after a particular session fails to achieve resolution. The point is to emphasize that all the warnings are in order despite the feeling that the mediator may not be needed again. Second, parties frequently want an evaluation because they believe it will be favorable to them. Attorneys want an evaluation because they believe it will make their clients more flexible (or benefit their clients). Evaluations, however, are likely to disappoint one (or sometimes all) of the players. Parties need clear, accurate, and reasonable expectations or a disservice can be rendered. A mediator does not want the final act (if it is the final act) of the mediation to do harm.

\section{STANDARD OF CARE IN PROVIDING OPINIONS AND EVAluATIONS}

How careful must a mediator be in providing an opinion or professional advice? If there is general disagreement and confusion about the required scope and content of informed consent relative to an evaluative service or process, the question of what standard of care applies to the evaluation or opinion itself mirrors that disagreement and confusion. Some of the various theories that apply to informed consent are relevant to the degree of care that must be exercised in providing an evaluation. These include the following: tort law, contract law, and fiduciary duty.

Under any theory one would expect the provision of an opinion to be done with care. Negligence law would apply a "reasonableness" standard. Contract law would ask what the agreement, or reasonable expectation, of the parties were. As a fiduciary, a mediator would need to honor carefully a trust relationship. Under any of these theories, one imagines a party expecting a thoughtful assessment. Alexander Pope said:

A little learning is a dangerous thing;

Drink deep, or taste not the Pierian spring:

There shallow draughts intoxicate the brain,

And drinking largely sobers us again. ${ }^{73}$

For example, a mediator who has seen many Blumberg form leases ${ }^{74}$

73 Alexander Pope, An Essay on Criticism, reprinted in THE NORTON ANTHOLOGY OF ENGLISH LITERATURE 2509, 2514 (Abrams \& Greenblatt eds., 7th ed. 2000).

${ }^{74}$ Blumberg Forms Online, http://www.blumberglegalforms.com/html/BFOoverview.html (for specific forms follow the "Select a Form" hyperlink). 
cannot blithely inform the parties in a noise dispute that since leases in urban environments require that $90 \%$ of the floor space be carpeted, the noisemaking neighbor must get a carpet. If that sort of advice is being requested and offered, the mediator should study the particular lease, and, if that mediator is licensed to practice law, he must determine what exceptions might exist. There is, after all, no rule without exceptions. "A little learning" is knowledge about the rule. "Drinking largely" opens up the world of shadows and exceptions.

We add to these points some principles:

- Always provide the basis and context of the evaluation. What "facts" were found or relied on? What "evidence" undergirds the evaluation? What expertise does the mediator have? What research is being undertaken?

- Always urge parties to get independent evaluations, listen to their own lawyers (if applicable), and consult their own judgment.

- Go to the library. That is, base the evaluation on a mode of thinking and conduct that an evaluator or opinion-giver would engage in. No lawyer, for example, should give an off-the-cuff opinion without research unless he identifies it as such and warns about its fallibility.

\section{CONCLUSION}

We have tried to enlarge the discussion on ethical boundaries and moral guideposts for mediator opinion-giving. Evaluation can be a risky move, and mediators should, as a base-line, do no harm in their practice. They should foster-and not undermine-party self-determination. Insuring informed consent for mediator evaluation both minimizes the possibility of harm and maximizes the possibility of self-determination. Put another way, parties should have a meaningful choice regarding whether their mediator uses the tool of opinion-giving and should be aware of the dangers involved when they make that choice.

When mediators do provide requested opinions, they should do so with care. They should consider what information they are basing their opinion on-is some of the "evidence" unreliable? That is, was it offered in a caucus where the other side had no opportunity to respond? Opinions based on such information are more likely to be unfair. Mediators should, metaphorically speaking, go to the library before giving advice. They should review, take time, and consult professional resources that would normally be doublechecked before a professional opinion was provided. At the very least, the parties should understand what the decision is based on and its qualitative difference from an opinion a judge, arbitrator, or neutral expert would make. 
Whether or not the mediator is willing to provide a requested evaluation should be known early, rather than late, in the mediation, as it will impact party willingness to share information and display flexibility. Consideration should be given to the use of the caucus, as ex parte communications can undermine the integrity of an evaluative role.

If mediation and justice are to be conjoined then the outcome in mediation must stay in the hands of the parties, and, to the extent the outcome is influenced by a neutral opinion, the requested opinion must be given with caution and care, adding to, not detracting from, the parties' capacity for meaningful self-determination. 
